Stanisław Garnczarski

ORCID: https://orcid.org/0000-0002-7245-5974

The Pontifical University of John Paul II in Krakow, Poland

\title{
Songs during the Canonization Mass of Blessed Kinga \\ Chaired by Pope John Paul II in Stary Sącz (June 16, 1999)
}

\begin{abstract}
The 7th Pilgrimage of the Holy Father to Poland was a special time for the Tarnowski Church community, because during the pilgrimage John Paul II was to come to Stary Sącz to canonize Saint Kinga. An important element of any liturgical meeting are song sand liturgical music. The present study aims to show various aspects of preparations in the musical field, from the liturgical theme of the celebration, through the performers, to the planned repertoire of songs. The canonization of Saint Kinga decided the subject matter of the texts, the performers were joined by choirs and orchestras, while the repertoire consisted of songs in honor of Saint Kinga, Eucharistic songs intended for the common singing of the entire community and choral works with orchestra accompaniment. Its character emphasized the very festive mood of this feast of faith.
\end{abstract}

\section{Keywords}

John Paul II, Saint Kinga, canonization, chants, songs, music, choir, orchestra. 
"Saints do not fade away. Saints draw life from other Saints and thirst for holiness".

The above words began the homily of John Paul II in the Starosądeckich common, read in his presence by Cardinal Franciszek Macharski, because of the viral infection that affected the Pope. Peter of our times, evoked the warm requests of the people of the Tarnów diocese for the canonization of Blessed Kinga, lifted up in Stary Sącz thirty years earlier, during the Millennium celebrations, chaired by the Millennium's Primate of Poland Stefan Wyszyński and bishop of Tarnów Jerzy Ablewicz.

The canonization of Blessed Kinga became the main reason for the arrival of Saint Peter successor - John Paul II - to Stary Sącz.

\section{Saint Kinga of Poland}

The cult of Saint Kinga developed spontaneously at the time of her death and continued for centuries, concentrating around her grave in the monastery of StarySącz. There she was always called „the holy Mother”. Miracles and numerous graces received by the prayers at Kinga's grave confirmed the widespread belief in the sacredness of Kinga. ${ }^{2}$

Kinga, or Kunegunda, was born on March 4, 1234 in Esztergom, as the daughter of the Hungarian King Bela IV and Maria of the Laskaris family. After five years she was engaged to the Duke of Sandomierz Bolesław, son of Leszek Biały. ${ }^{3}$ It was then that she first came to Wojnicz, then to Sandomierz, and she built a heartfelt relationship with the mother of her future husband, Grzymisława and her daughter Salomea. Both of them were distinguished by deep religiosity, ascetic life and love for prayer, reading the Holy Scriptures and the lives of saints. Their cordial accompaniment, especially in the difficult, first years of their stay in Poland, had a great impact on Kinga. The ideal of holiness increasingly matured in her heart. Searching for role models that could correspond to her status,

${ }^{1}$ Jan Paweł II, Homilia podczas mszy kanonizacyjnej bt. Kingi w Starym Sączu (16 VI 1999), „Currenda” No. 149 (1999), Special issue, p. 25. Translation: https://w2.vatican.va/content/ john-paul-ii/en/homilies/1999/documents/hf_jp-ii_hom_19990616_stary-sacz.html

${ }^{2}$ R. Banach, Proces kanonizacyjny bł. Kingi, „Currenda” No. 149 (1999), Special issue, p. 56.

${ }^{3}$ Msza święta i kanonizacyjna Błogosławionej Kingi. Stary Sącz 16 czerwca 1999, eds. B. Margański, A. Zając, S. Garnczarski, et al., Tarnów 1999, p. 13. 
she chose her sacred relative - Princess Jadwiga Śląska as the special patron. She also wanted to indicate to Poland a saint who would become for all the states and all districts a teacher of love for the Motherland and the Church. Therefore, together with the Bishop of Kraków, Prandota of Bialaczew, she made efforts to canonize the Krakow martyr, Bishop Stanisław of Szczepanów. Certainly, the living Saints exerted considerable influence on her spirituality: Saint Jacek, Blessed Sadok, Blessed Bronisława, Blessed Salomea, Blessed Jolanta - Kinga’s sister and all those who created a special environment of faith in Kraków at that time. ${ }^{4}$ After the death of her husband, the Duke of Sandomierz, she helped generously to build the monastery of the Poor Clare community in Stary Sącz (part of the monastery's walls is still preserved today), to which she herself entered. Enamoured in prayer and liturgy, she organized the formation of new parishes, built churches, and carried out exemplary religious life, which, especially in the heroic, austere asceticism, was marked during her long and painful illness. In the memory of the contemporaries, she remained primarily as a merciful "mother of the poor and all those who are distressed”. Her canonization was planned during the Holy Mass on June 16, 1999 in the monastery grounds, which she herself funded, inhabited and in which she was buried. ${ }^{5}$

\section{The content of the liturgical texts of the canonization mass}

The proper selection of songs in each liturgical celebration depends primarily on the content of the texts used in the liturgy. It indicates their subject. Of course, this celebration was one of many during the entire pilgrimage, therefore, after initial arrangements by the relevant instances of the Holy See and the Polish Episcopate regarding the program of the VII Apostolic Visit of the Holy Father to Poland to be held in June 1999, in Gniezno (at the premises of the Primate's Theological Seminary) on June 30, 1998, the first joint meeting of all presidents of the diocesan liturgical commissions of the Papal Pilgrimage with ,the National Responsible" of Liturgical Commission took place. Throughout this long meeting many indications were widely discussed regarding issues such as: location

\footnotetext{
${ }^{4}$ Jan Paweł II, Homilia podczas mszy kanonizacyjnej bł. Kingi w Starym Sączu (16 VI 1999), in: „Currenda” No. 149 (1999), Special issue, pp. 26-27.

${ }^{5}$ J. Stefański, Tu es Petrus, https://www.academia.edu/33984756/Ks._Jerzy_ Stefa\%C5\%84ski_-_Tu_es_Petrus, pp. 27-28.
} 
and development of space for the celebration, concelebration, vestments and liturgical paraments, assists, diagrams of a typical and shortened Devotion of the Word of God (or other church services), a method of efficiently distributing Holy Communion to the faithful through several hundred ordinary and extraordinary ministers of Holy Communion. ${ }^{6}$ However, it was also undertaken to prepare the celebration itself by choosing the texts of biblical readings, followed by integral texts along with Latin rubrics or notes (e.g. mass prefaces) referring to a particular liturgical celebration that the Holy Father was supposed to preside over. They were asked to provide Italian (Latin or French) translation of all the texts that had not been officially approved by the church authorities. This concerned above all, the texts of the calls to Universal Prayer, the introductions to the penitential act of Mass, and to the "Credo" etc.

Preparations for the Apostolic Visit in the liturgical dimension were conventionally seen to in the meeting of the national Responsible at the seat of the Papal Ceremonies Office in the Vatican with the head of this Office Bishop P. Marini and the only Pole working in this Office - Fr. Doctor Konrad Krajewski -the papal master of ceremonies. These working meetings lasted over a week, from February 27 to March 6, 1999. Every sentence, every detail of the celebration was subject to review. The aim of this work was to prepare and elaborate the texts of the liturgical rites so that they could constitute the so-called Papal Missal of the VII Apostolic Visit of Holy Father in Poland between June 5-17, 1999.

After precise determination by Bishop Jan Chrapek (national coordinator of the Holy Father's visit to Poland) all technical and logistical details related to the stay of Fr. Bishop P. Marini between the $6-17$ April 1999, the next meeting of all diocesan presidents of the papal liturgical commissions to Gniezno was convened on March 15, 1999. All interested persons were informed in detail about the final celebrations made by the Master of Pontifical Ceremonies regarding the texts and all the rites of the prescribed Papal Liturgy. ${ }^{7}$

The texts arranged and approved for the celebration in Stary Sącz focused around St. Kinga, whose canonization was to take place during the Holy Mass on the Starosądeckich common lands. So the Mass form was about the Saint:

The collect: God, You have given Saint Kinga a generous blessing and kept a virgin even in a marriage, + help us, through her intercession, so that we can,

\footnotetext{
${ }^{6}$ J. Stefański, Tu es Petrus, p. 22.

7 J. Stefański, Tu es Petrus, p. 26.
} 
through the purity of life, always stay with you ${ }^{*}$ and following her footsteps could come to You. Through our Lord...

Prayer over the gifts: Almighty God, we glorify the wonders of Your grace in Saint Kinga, the virgin, + and humbly ask You * to make our Sacrifice pleasing to You, just like her holy life. Through Christ...

Prayer after the Holy Communion: God, our Father, may the sacrament received through the merits of Saint Kinga, the virgin, constantly stimulate us to the good and enlighten us, + so that we may look forward to the coming of your Son * and are admitted to His heavenly feast. He who lives and reigns... ${ }^{8}$

The texts of the readings were selected as follows:

The first reading was taken from the Book of Tobit - Tb 13, 11-14 and contains Tobit's song of praise, especially his second part, saying that „God will show His mercy to the Chosen People because they themselves will rebuild the Temple of Jerusalem. (...) Then the second theme is introduced, Zion as a spiritual place, to which not only the returning Jews are heading, but also the pilgrim nations that seek God. The universal horizon opens before us: the rebuilt Jerusalem temple, the sign of the word and the presence of God, will shine with the light of stars, which will dissipate the darkness so that «many nations and inhabitants from far away» (see verse 13) can go on their way, carrying gifts and singing with joy, because they participate in the salvation that the Lord gives Israel."

As singing, was selected the Psalm 45 (44), 11-12.14-15.16-17, entitled: Song for a Royal Wedding. The chosen refrain left no doubt that it is about Christ-, ,Christ is coming, come for the meeting". The second reading was a passage from the First Letter to the Corinthians - 1 Cor 7, 25-35 and draws the attention of the faithful to the value of celibacy and marriage. The Apostle teaches that virginity, or voluntary celibacy, results only from the evangelical council - and that under appropriate conditions it is "better” than a marriage which is by no means a $\sin .^{10}$ The Gospel chosen was Matthew's parable of the wise and foolish virgins (Mt 25,

8 Visitatio pastoralis Summi Pontificis Joannis Pauli PP. II in Polonia. Diebus 5-17 Junii A. Domini 1999, pp. 369-393.

9 Jan Paweł II, General audience, August 13, 2003 in: https://opoka.org.pl/biblioteka/W/ WP/jan_pawel_ii/audiencje/ag_13082003.html (26.04.2019).

10 Jan Paweł II, „Mężczyzna i niewiasta stworzył ich...”, vol. III, Lublin 2001, http://www. kbroszko.dominikanie.pl/min_t3_2bc.htm (26.04.2019). 
1-13). It is part of Jesus' eschatological speech. In it, He calls for the vigilance ${ }^{11}$ which Saint Kinga has shown in her life.

The content of the above texts became the basis for the selection of singing performed during the celebration. The selected repertoire will be shown below.

\section{Preparations in the musical field}

Preparations for the visit of the Holy Father John Paul II in Stary Sącz began with the appointment of the Diocesan Team for the Preparation of the Pilgrimage of the Holy Father John Paul II to Stary Sącz, by the Tarnów Bishop Victor. The Team included seven commissions: Pastoral Affairs, Liturgical, Legal and Administrative Affairs, Order Policy, Health Service, Social Communications, Information and Publishing. What is of most interest for this paper is the Liturgical Commission, which included the church musicians: Fr. Kazimierz Pasionek, Fr. Andrzej Zając and writing these words - Fr. Stanisław Garnczarski ${ }^{12}$. Of course, many more people took part in the preparations, but we will talk about them later in the study. The selection of the repertoire was supervised by Fr. Kazimierz Pasionek and Fr. Andrzej Zając. The latter also undertook to lead the music band as a conductor. The author prepared the scores for their computer composition and extracts for individual orchestral sections.

The huge so-called "papal choir” consisted of sixteen choirs, including six from Nowy Sącz: the Chamber Choir of the Basilica of St. Małgorzata, the choirof John Paul II from the parish of the Sacred Heart of Jesus, the choir „Echo II" from the parish of St. Kazimierz, the choir "Immaculata” from the parish of Our Lady Immaculate, the choir from the parish of Our Lady of Sorrows, the choir „Scherzo" from the I High School of Jan Długosz. The Nowy Sącz choirs were also joined by: from Marcinkowice - the choir of Fr. J. Popiełuszko; from Tarnów the Boy's Cathedral Choir „Pueri Cantores Tarnovienses”, the Choir of the Major Theological Seminary, the mixed choir „Magnificat” from the parish of Blessed Karolina and the Girls' Cathedral Choir „Puellae orantes”; from Bochnia - the Boys' Choir „Pueri Cantores S. Nicolai”; from Limanowa - the Boys' Choir

${ }^{11}$ Komentarze biblijne do czytań mszalnych, Year A, ed. Homerski J. et al., Lublin 1981, p. 223.

12 S. Sojka, Przygotowanie diecezji tarnowskiej na przyjazd Ojca Świętego Jana Pawła II do Starego Sącza, „Currenda” No. 149 (1999), Special issue, pp. 65-66. 
of the Basilica of Our Lady of Sorrows; from Tuchów - the Shrine Mixed Choir and the Choir of the Redemptorists Major Seminary; from Mielec - the Choir of the parish of Our Lady of Perpetual Help. ${ }^{13}$

The choirs were accompanied by five connected orchestras: the Representative Orchestra of the Carpathian Border Guard Unit in Nowy Sącz, the Brass Orchestra of Zakładów Naprawczych Taboru Kolejowego SA from Nowy Sącz, and the Brass Orchestra of the Musical Center of Tadeusz Moryta in Łącko, the Brass Orchestra "Glinik” of the Music Enthusiasts Association of Professor Jan Skowroński’s in Gorlice and the Starosądecka Brass Orchestra.

\section{The repertoire of songs}

The songs chosen for the canonization ceremony of Saint Kinga were in accordance with the liturgical texts and the rites which accompanied them. Many of them had been composed in connection with the celebration or for the worship of the future Saint. The rest were taken from the already existing rich treasury of church music. Their development was based primarily on the preparation a choral score and instrumentation for the orchestra accompanying the singing.

\subsection{Songs in honour of St. Kinga}

The most numerous group were songs in honour of Saint Kinga -there were five of them. Because they relate strictly to the canonized person, they will be discussed in more detail.

The first two were intended to be sung at the beginning of the Holy Mass: Ziem sądeckich sławna Pani, Kingo! and Jak przed wiekami.

Ziem sadeckich sławna Pani, Kingo! (Example 1) was written by Fr. Władysław Wojtoń SJ, both in terms of text and melody. He was (born on October 13, 1869 in Trześniów near Brzozów - died September 20, 1948) an outstanding Jesuit educator and priest. He was ordained by Bishop Anatol Nowak on June 28, 1901. His passion was poetic creativity, hence he wrote many texts for church songs. He was the editor of Posłańca Serca Jezusowego, and from November

13 J. Nowak, Kronika uroczystości kanonizacyjnych w Starym Sączu, „Currenda” No. 149 (1999), Special issue, p. 78. 
1915 - the moderator of the Academic Marian Sodality. He also served in the field of Catholic Action. ${ }^{14}$

The text was written in four-line stanzas, isosyllabic, in 15-syllable lines with a caesura $8+7$. The strophes are characterized by masculine rhymes at the end of verses, while feminine, accurate rhymes are in caesura. Both types are paired rhymes (aabb).

In terms of musical form, this is a 16-bars song, with a two-part form, with different parts $(A B)$, built symmetrically $(8+8)$, in which both sentences consist of two 4-bars phrases: $A\left(a b+a b_{1}\right)+B\left(c_{1}+c_{2} d\right)$.

The second song performed as an entrance hymn was Jak przed wiekami (Example 2). The author of the text was S.M. Teresa Izworska OSC - she was the prioress - the Order of the Poor Clares in Stary Sącz. And the music was composed by Fr. Kazimierz Pasionek (born on March 1, 1930 in Żmiąca near Limanowa, died on November 29, 2006 in Tarnów) musician, composer, educator and teacher. ${ }^{15}$

The text is enclosed in four-line stanzas, various verses, with a fixed scheme of measures: $10+9+10+9$. Stanzas are bound with alternate rhymes (abab), wherein rhyme "a" is feminine, paroxytonic, exact, while rhyme „b” is masculine, oxytonic and exact rhyme.

It is an 8-bars song, with a two-part form, with different parts $(\mathrm{AB})$, built symmetrically $(4+4)$, in which both sentences consist of two 2-bars phrases: $\mathrm{A}(\mathrm{ab})+\mathrm{B}(\mathrm{cd})$.

After the Holy Father delivered the canonization formula, at the translation of the relics of Saint Kinga and the deposition at the altar the Invocation performed was - Kingo, Sadecka Pani (Example 3). The author of the text and the melody was Fr. Kazimierz Pasionek. The singing was divided for various performers, namely, the people under the guidance of the schola sang, and the verse was sung solo by a baritone.

The song is an example of a refrain form. It begins with a 4 verse of constant refrain, repeating after each strophe. It is followed by a 4-verse strophe. The verses, both in the refrain and stanzas, are heterosyllabic with a fixed pattern of measures: $7+6+7+6$. The refrain is included in 8 bars in the meter „C”, and

${ }^{14}$ K. Jarkiewicz, Skromny, prosty i nie taki - Władysław Wojtoń SJ (1869-1948) $w$ duszpasterstwie i edukacji, in: Studia i materiały do dziejów jezuitów polskich, eds. A.P. Bies, L. Grzebień, vol. 20 Społeczeństwo, kultura, wychowanie w poglądach polskich jezuitów okresu II Rzeczypospolitej, ed. S. Cieślak i B. Topij-Stępińska, Kraków 2012, pp. 89-117.

15 S. Garnczarski, Pasionek Kazimierz, in: Polish Music. Polish Composers 1918-2010, edited by M. Podhajski, Gdańsk-Lublin, 2013, pp. 957-959. 
the stanza in 4-bars, in the 5/4 meter. The rhymes appearing in the refrain and strophe are feminine, paroxitonic accurate - „a” and masculine, oxytonic, accurate -„,", the rhymes occur alternately (abab).

In the aspect of architectonics, we are dealing with a two-part form, with different elements $(\mathrm{AB})$. Each section is divided into two sentences: in the refrain - 4-bars, in the stanza - 2-bars. The scheme is as follows: $A\left(a b+a_{1} b_{1}\right)+$ $B\left(c d+c_{1} d_{1}\right)$.

For the Presentation of the Gifts the song Jaka piękna jesteś Kingo (Example 4) was sung, with the text of Marek Skwarnicki and the music of Jan Gładysz.

Marek Skwarnicki (born April 30, 1930 in Grodno, Belarus, died on March 12, 2013 in Krakow) was a Polish poet, columnist, novelist and translator. In 1976 he was appointed by Pope Paul VI a member of the Pontifical Council for the Laity. He was a member of the editorial office of „Tygodnik Powszechny” and "Znak". ${ }^{16}$

Jan Mikołaj Gładysz (born in 1956 in Rabka) musicologist, composer, organist and conductor of the choir in the Sanctuary of Our Lady in Tuchów. He worked as a teacher in the Diocesan Studium, as Organist in Tarnów and in the Social Music Center of I.J. Paderewski in Tuchów. ${ }^{17}$ Today he is the director of the 1st degree Music School in Tuchów. ${ }^{18}$

The song lyrics of Jaka piękna jesteś Kingo is enclosed in four-line stanzas, isosyllabic, with 16 -syllable lines with a caesura $(8+8)$. The rhymes connecting the stanza are paired, paroxitonic, accurate, except for a few, with a modified phonic and articulation source: in varieties „ą-o", e.g. królową-słowo and „ę-e”, e.g. nadzieję-wietrzeje. An example of a feminine, paroxitonic, inaccurate rhyme is: zorzy-stworzyl.

The architectonics of this song, contained in the 16-bars song, reveals its two parts with different parts (AB). Each of the parts consists of two 4-bars sentences, with an upbeat, designated by particular verses. The scheme is as follows: A $\left(\mathrm{aa}_{1}\right)+\mathrm{B}(\mathrm{bc})$.

The last of five songs in honour of Saint Kinga, performed during the canonization Mass in Stary Sącz is Bądź uwielbiony (Example 5), performed as praise

${ }^{16}$ Marek Skwarnicki, https://www.znak.com.pl/autor/Marek-Skwarnicki (1.05.2019).

17 De cantu sacro. Biuletyn Stowarzyszenia Polskich Muzyków Kościelnych, no. 8, ed. G. Poźniak, Opole -Lublin 2013, p. 72.

18 Szkoła muzyczna I stopnia w Tuchowie, http://www.sm.tuchow.pl/o-szkole/o-nas/ (1.05.2019). 
after the Holy Communion. The text was written by S.M. Teresa Izworska OSC, and music composed by Fr. Kazimierz Pasionek.

It is a refrain form, containing three stanzas interspersed with a constant refrain. The stanzas and refrain are 4 verses, wherein the stanza is isosyllabic, with the 11-syllable line, and the refrain is heterosyllabic, with a fixed diagram of verse measures: $11+8+11+8$. Both stanzas and the refrain are linked with alternating rhymes, in the stanzas feminine, paroxitonic and accurate rhymes, while in refrain, in addition to those mentioned, there are also masculine, oxitonic, accurate rhymes (nam-sam).

In terms of the architectural structure, this song - 16-bars - presents a twopart form, with different parts $(\mathrm{AB})$, the first of which is a stanza, the second a refrain. Each sentence consists of two 2-bars phrases, designated by each verse: $A\left(a a_{1}+b b_{1}\right)+B\left(c d+c d_{1}\right)$.

\subsection{Eucharistic songs}

Another group of songs performed in Stary Sącz during the canonization Mass by all participants were four Eucharistic songs. They are widely known, so we will not analyze them in detail, but we will only mention and provide short biographies of their creators.

Two were intended for the Communion: Bądźże pozdrowiona and Zróbcie $\mathrm{Mu}$ miejsce. The creator of the text for the first song was Fr. Teofil Jarynkiewicz (born in 1850, died on September 20, 1918 in Krakow) cathedral vice-dean, titular canon, prebendary at the Church of Divine Mercy on Smoleńsk in Krakow. Ordained in $1873 .{ }^{19}$ We do not know who composed the melody. The text of the second song was written by Franciszek Karpiński (born on October 4, 1741 in Hołoskow near Otynia, died on September 16, 1825 in Chorowszczyzna near Wołkowysk), Polish poet of the Enlightenment, creator and main representative of the sentimental trend in Polish lyric poetry. In the years 1785-1818 he stayed at the Branicki manor house in Bialystok, where he wrote Pieśni nabożne, published in the monastery of Basilian monks in Supraśl in 1792. ${ }^{20}$

19 Ks. Teofil Jarynkiewicz, Ilustrowany Kuryer codzienny, no. 169, September 23, 1918, Kraków, p. 4.

20 S. Garnczarski, Polska pieśń adwentowa w drukach od XVII do XX wieku, part I, Tarnów 2014, pp. 191-192. 
The worship hymns sung after Holy Communion, apart from, the song discussed above Bądź uwielbiony, were two others songs O Boże, dzięki Ci składamy, and Cóz $\dot{z} i$, Jezu damy. The text to the first one was written by Fr. Stanisław Ziemiański SJ (born on September 7, 1931 in Besk) - a Jesuit, philosopher, songwriter and the composer of melodies ${ }^{21}$, and the melody was composed by Fr. Marian Michalec CM (born on July 30, 1936 in Świątniki Górne near Kraków, died on October 11, 1997 in Krakow), a priest of the Congregation of Missionaries, musicologist, lecturer of the church music. ${ }^{22}$

We only know the composer of the melody of the second song - Roman Dwornik (born on February 14, 1913 in Szarleju, died on April 23, 1988), an organist, composer and lecturer of music. ${ }^{23}$

\subsection{Choral works with orchestra}

In addition to the songs during the liturgy, other works for the choir and orchestra were written. During the offertory the motet Afferentur regi was performed, composed by Anton Bruckner (born on September 4, 1824 in Ansfelden near Linz, died on October 11, 1896 in Vienna), an Austrian composer, musician and music teacher. ${ }^{24}$ The motet was composed on November 7, 1861, based on the Offertorium text from Missa pro Virgine et Martyre. The text comes from Psalm 45 (44), 15-16, and the work had its premiere at the Abbey of Saint Florian on the Feast of Saint Łucja, December 13, 1861.

The same composer was the author of another motet performed during the Communion rite-Tantum ergo. It was created in the autumn of 1845 at the end of Bruckner's stay in Kronstorf or at the beginning of stay in the Abbey of Saint Florian. Tantum ergo are the two last verses of the hymn Pange lingua gloriosi, the Eucharistic hymn composed by Saint Thomas Aquinas.

The motet Ave Verum also was intended for the time of the Communion rite the motet was composed by Floora Peeters (born on July 4, 1903 in Tielen, died

${ }^{21}$ Ks. Stanisław Ziemiański, https://sziemianski.wordpress.com/ (2.05.2019).

22 S. Garnczarski, Polska pieśń adwentowa..., p. 147.

${ }^{23}$ S. Garnczarski, Polska pieśń adwentowa...,p. 166.

24 A. Chodkowski, Bruckner Anton, in: Encyklopedia MuzycznaPWM, vol. 1 „ab”, ed. E. Dziębowska, Kraków 1979, p. 434. 
on July 4, 1986 in Mechelen), a Belgian composer, organist and teacher. The text is the Eucharistic hymn from the fourteenth century by an unknown author. ${ }^{25}$

After the rites of dismissal the choir and the orchestra performed the ceremonial Laudate Dominum - composed by Charles Gounod (born June 17, 1818 in Paris, died on October 18, 1893 in Paris) a French composer and musician. ${ }^{26}$ The work performed on the commonlands of Stary Sącz was arranged by Fr. K. Pasionek.

There is one more piece left which was performed before the liturgy, to welcome the Holy Father entering on the coronation square. This is Tu es Petrus composed by Wacław Gieburowski (born on February 6, 1878 in Bydgoszcz, died on September 27, 1943 in Warsaw). ${ }^{27}$

\subsection{Other songs}

During the canonization Mass, mainchants were taken from the Mszy Jubileuszowej of Fr. Kazimierz Pasionek, which he composed for the 2ooth anniversary of the Diocese of Tarnow, celebrated solemnly in 1986. The mass was prepared for orchestra, choir and the people included: the Kyrie, Gloria, Sanctus and Agnus Dei.

In addition, performed with singing before the Gospel was the Alleluja (Example 6) with Haec dies composed by Jh. Jongen in 1895 and at the end of the Eucharistic Prayer - the Amen (Example 7).

To sum up, it should be stated that the selected repertoire of songs for the canonization ceremony of Saint Kinga was properly selected, both in terms of theme and performance. Most of the songs referred to Saint Kinga, and the division due to performers, was in favour of the singing of the community, and not just the choir itself. The challenge was to work out most of the songs for both the choir and the community. This is how they were worked out e.g. all the main chants from the Jubilee Mass of Fr. Kazimierz Pasionek. In addition, the high standard of the performance certainly contributed to the deeper experience of the secrets of faith celebrated together with Saint John Paul.

${ }^{25}$ Ave verum, in: Leksykon liturgii, study by B. Nadolski, Poznań 2006, p. 128.

26 A. Konieczna, Gounod Charles, in: Encyklopedia Muzyczna PWM, vol. 3 „efg”, ed. E. Dziębowska, Kraków 1987, p. 410.

27 S. Garnczarski, Polska pieśń adwentowa..., pp. 153-154. 


\section{Examples}

\section{Example 1.}

\section{Ziem sądeckich}

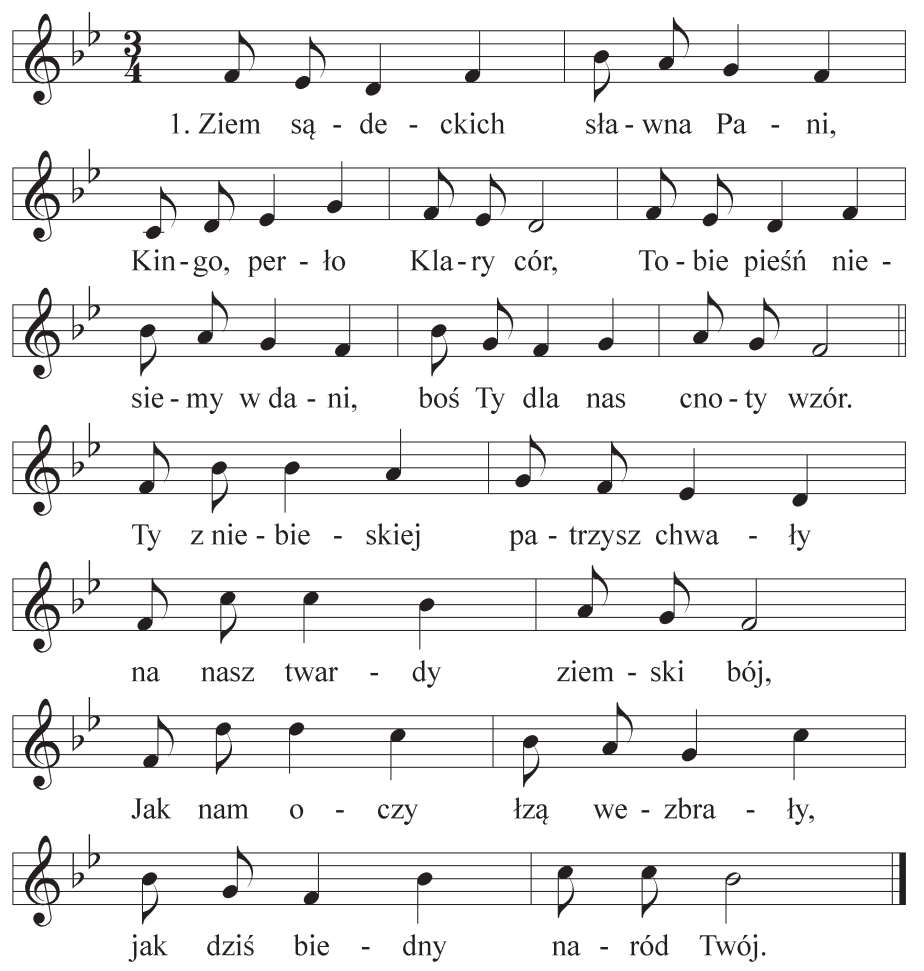

2. Wszak nam Królową byłaś, więc niedolę naszą znasz, * Zawsze o lud się troszczyłaś, to i dla nas serce masz. * Dziś wypraszaj łaski z nieba, by w świętości wytrwał lud, * I ziemskiego uproś chleba, aby nas nie nękał głód.

3. Tyś się Bogu poświęciła strojąc duszę w kwiatu wian, * Przez Twe dłonie Matko miła cud niejeden zdziałał Pan. * Chroń swój Klasztor Kingo droga, Naród polski broń i strzeż; * Wszystkich prowadź przed tron Boga, w szczęśliwości wiecznej zbierz. 


\section{Example 2.}

\section{Jak przed wiekami}

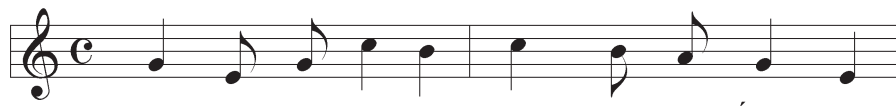

1. Jak przed wie - ka - mi spójrz Kin - go Świę - ta

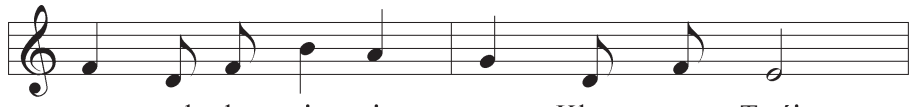

na pol-ską zie-mię, na Klasz - tor Twój,

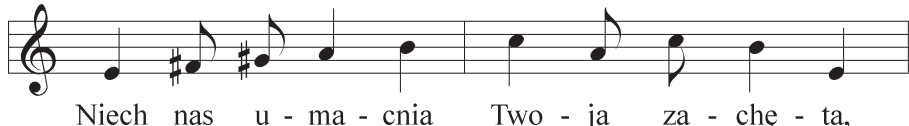

Niech nas u - ma - cnia Two - ja za - chę - ta,

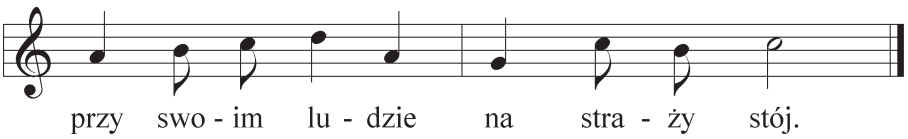

2. By został wierny Bogu, krzyżowi * i Ewangelią na codzień żył, * Poddając zawsze ciało duchowi, * miłował Boga ze wszystkich sił.

3. Ty piękno życia nam ukazałaś, * dla Ciebie wszystkim był Chrystus Pan, * Swe czyste serce Jemu oddałaś, * moc czerpiąc z Jego Najświętszych Ran.

4. Sławimy Ciebie słowem, pieśniami, * ukazujemy jako nasz wzór, * O powołania módl się za nami, * w szeregi Twoich duchowych cór.

5. Pamiętaj o nas przy Bożym tronie, * wspierając truduziemskiego czas, * Patronko nasza, wyciągnij dłonie, * jak dobra matka przygarnij nas. 


\section{Example 3.}

\section{Kingo, sądecka Pani}
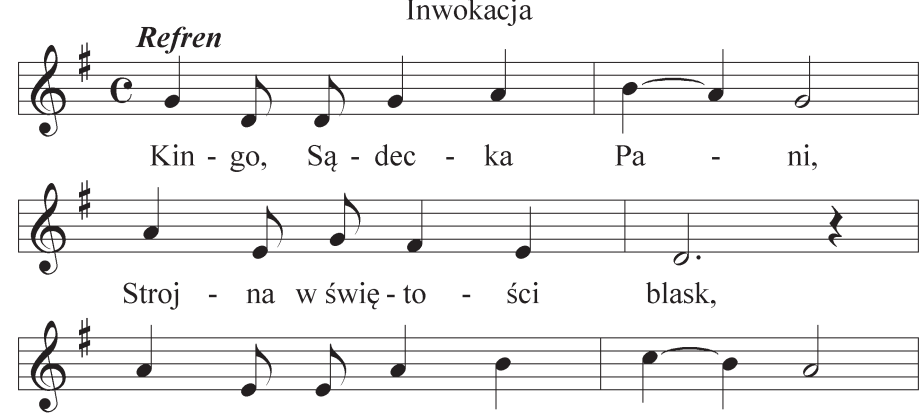

Hoł - dem skła - da - nym w da - ni,

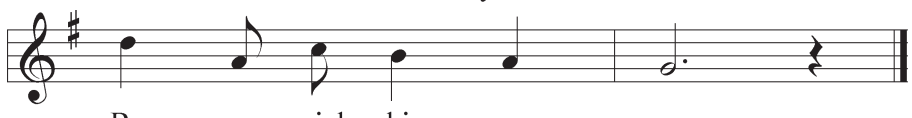

Bo - ga wiel - bi - my wraz.

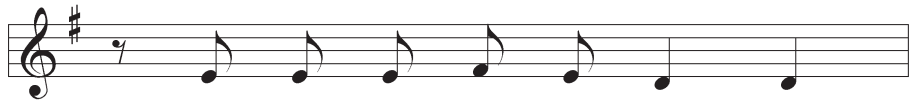

1. Po - patrz z oł - ta - rza chwa - ły

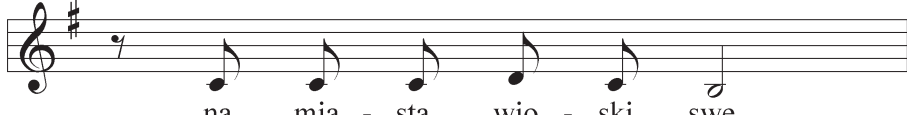

na mia - sta, wio - ski swe,
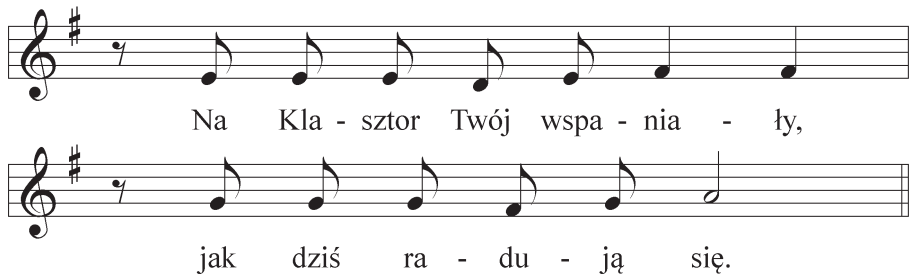

2. Proś Boga Ojca w niebie, * porękę za nas daj, * Orędownictwem swoim * obejmij cały kraj. * Kingo...

T i M: K. Pasionek 


\section{Example 4.}

\section{Jaka piękna jesteś Kingo}

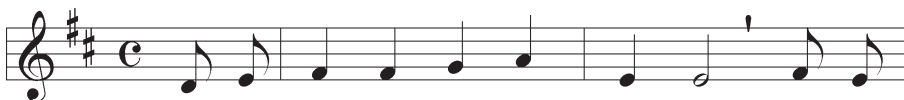

1. Ja - ka pię-kna je - steś Kin - go w mi-ło -

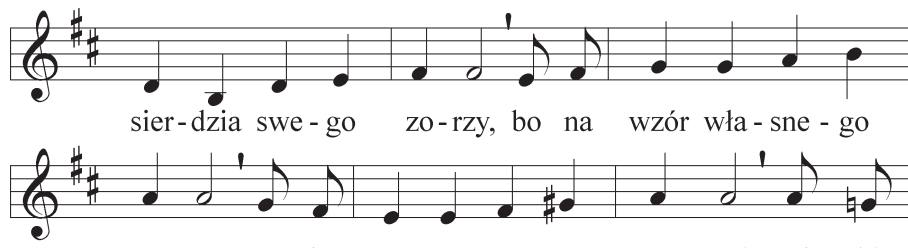

Ser-ca Two-je ser-ce Pan Bóg stwo-rzył. Dziś skła-

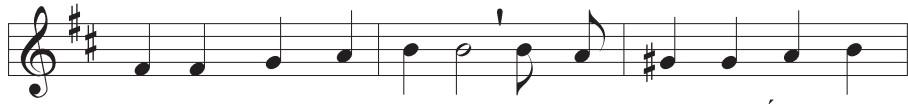

da-my w Two-je rę-ce, sła-wna cór-ko Świę-tej
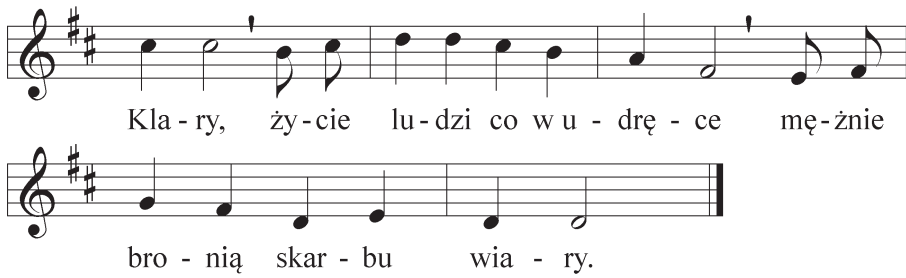

2. Pan Bóg skrawek swej dziedziny, * polskiej ziemi Ci wydzielił, * góry śliczne i doliny śpiewem ptaków rozweselił. * I Pieniny Stwórca przeciął ostrzem dunajcowej klingi, * Tatr koroną opromienił piękną ziemię Świętej Kingi.

3. Ty, co byłaś na tej ziemi dobrodziejką i królową, * przemów dziś do Pana świata za swych wiernych dobre słowo. * W Tobie bowiem Siostro Kingo pokładamy swą nadzieję, * bo w Twej duszy Chrystus ukrył sól, co nigdy nie wietrzeje. 


\section{Example 5.}

\section{Bądź uwielbiony}

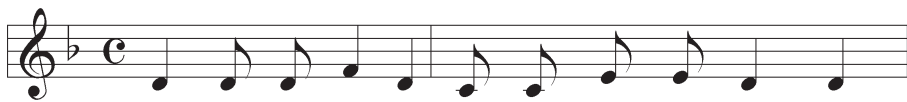

1. Bądź u - wiel-bio-ny Oj-cze, Stwór - co świa - ta,

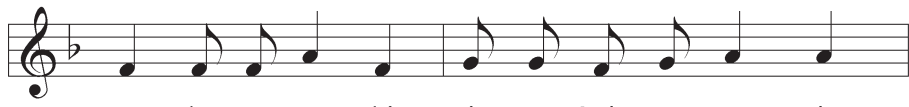

$\mathrm{Za}$ dar Pa-tron - ki i za świę-te ży - cie,

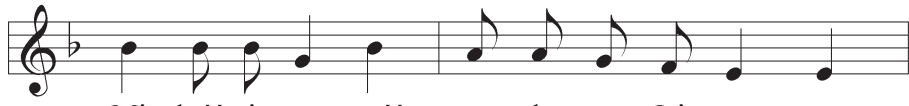

Mi - łość i czy-stość go - do - wa Jej sza - ta,

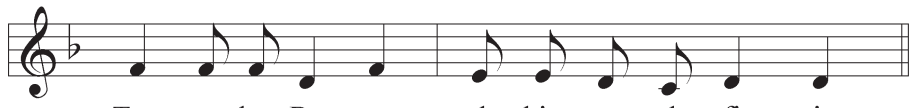

Twą rę-ką, Bo - że, zdo-bio - na ob - fi - cie.

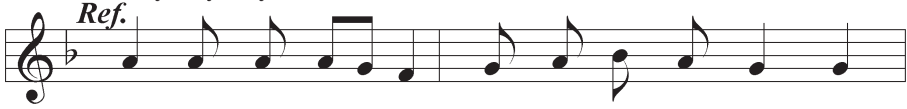

Naj-świę-tsza Trój- co, niech Ci bę-dzie chwa - ła

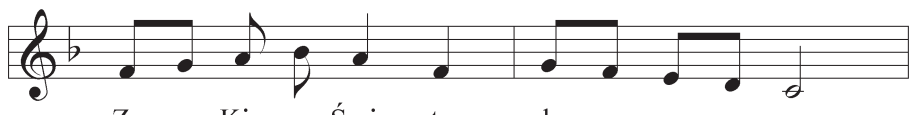

Za Kin-gę Świę - tą da - ną nam,

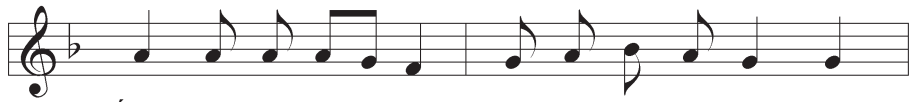

Świa - tło-ścią ła - ski Two-jej za - ja - śnia - ła,

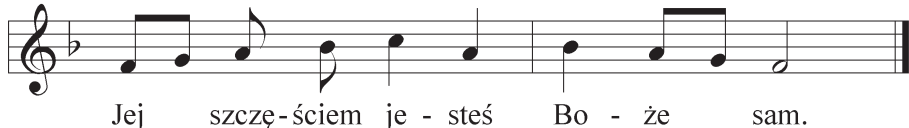

2. Bądź uwielbiony Panie Jezu Chryste, * Ty człowiekowi Serce swoje dałeś, * Raczyłeś zawrzeć przymierze wieczyste * I do szczególnej miłości wezwałeś.

3. Bądź uwielbiony Duchu Święty Boże, * Za Twoje dary i moc uświęcenia, * Że ludzkie serce rozśpiewać się może, * jak sanktuarium, hołdem uwielbienia. 


\section{Example 6.}
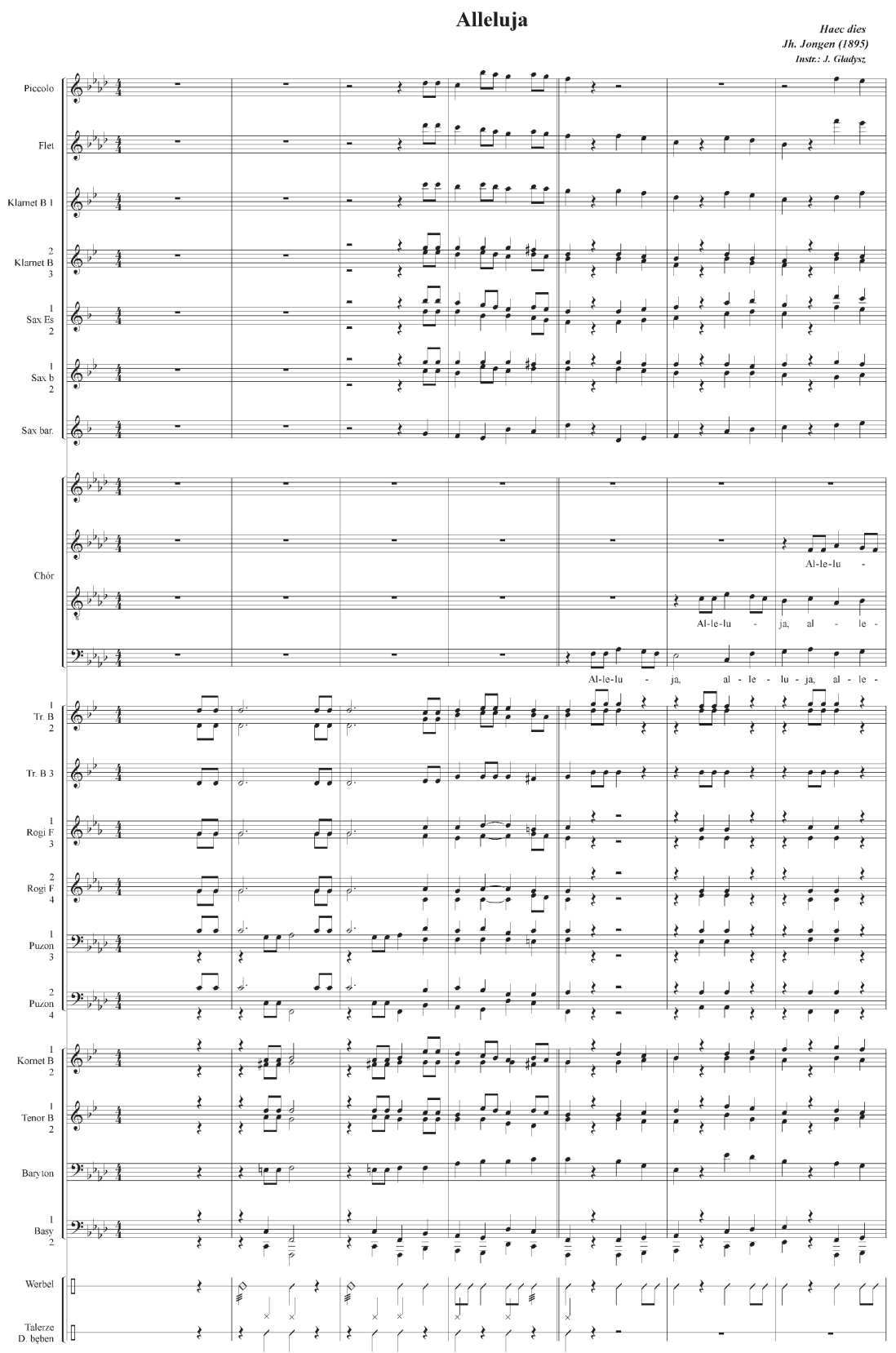


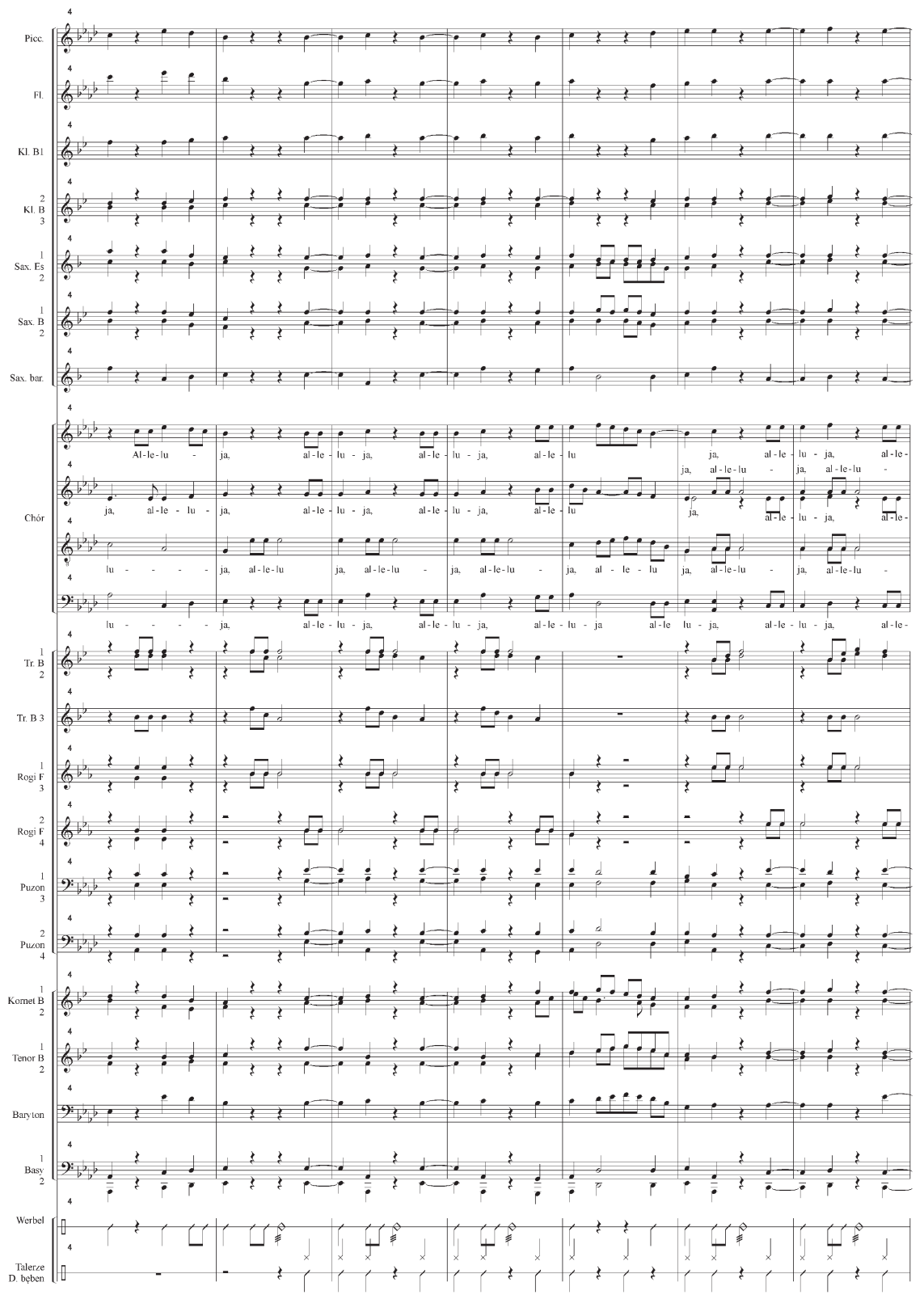




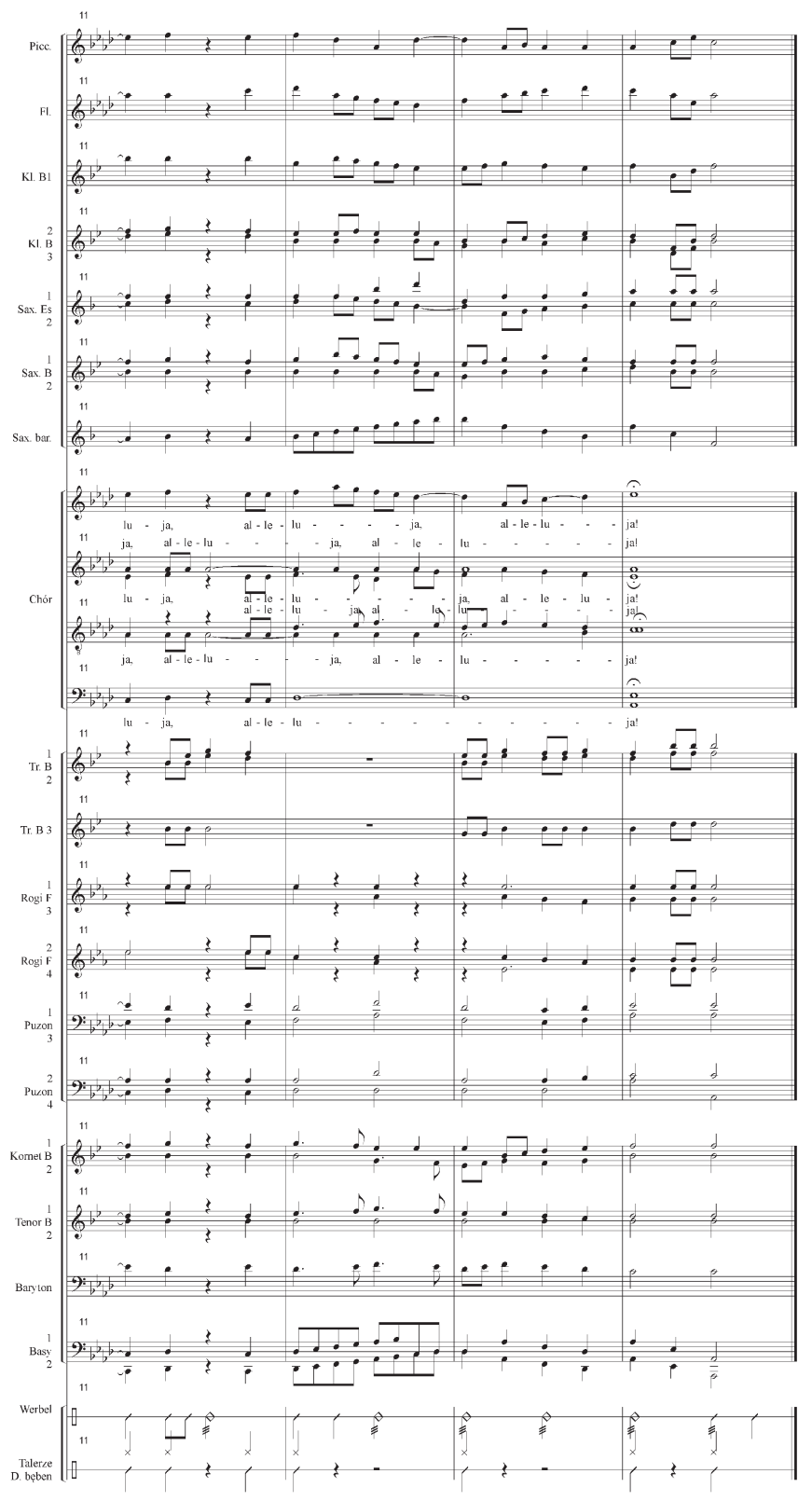




\section{Example 7.}
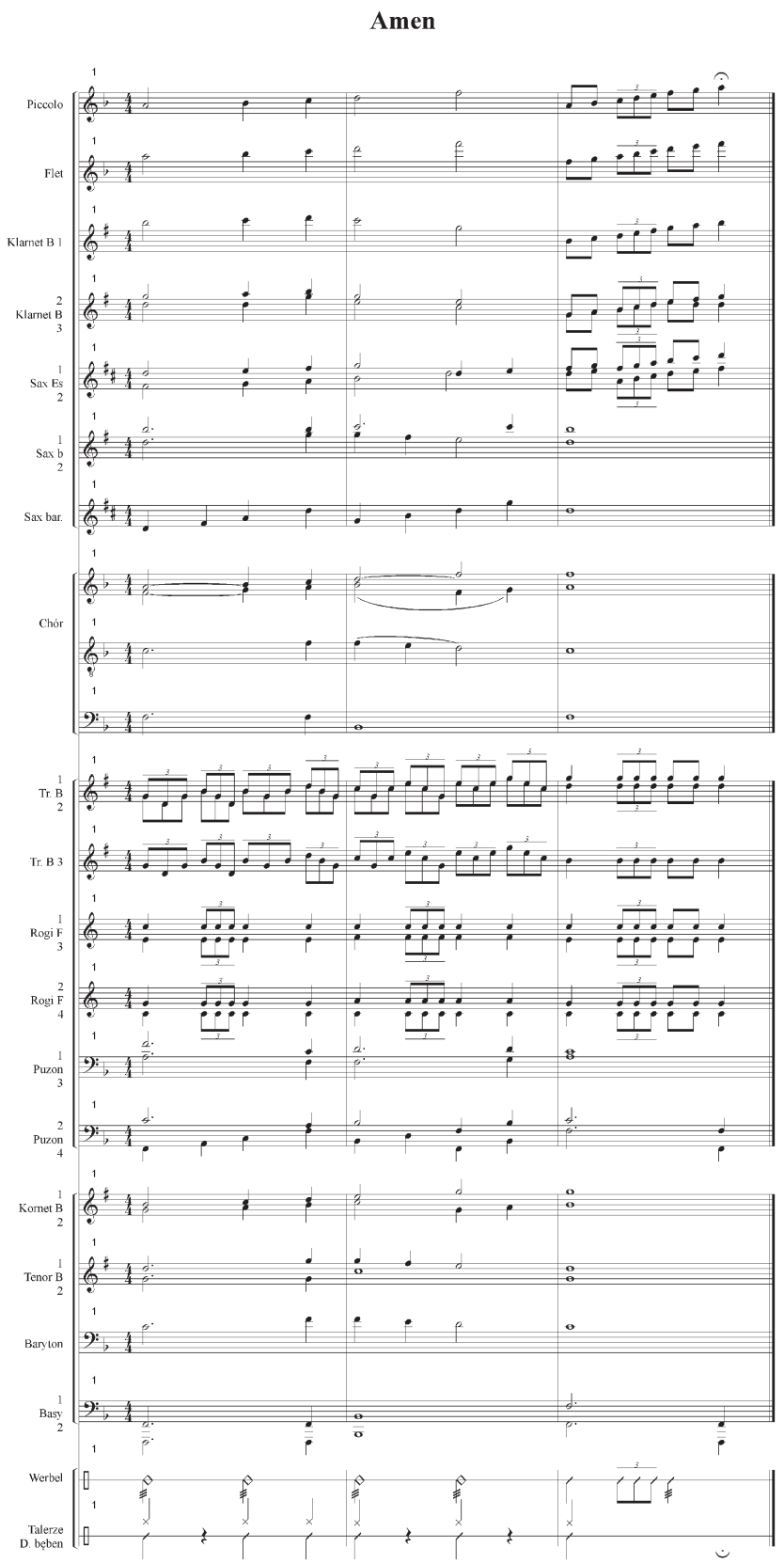


\section{Bibliography}

Ave verum, in: Leksykon liturgii, ed. B. Nadolski, Poznań 2006, p. 128.

Banach R., Proces kanonizacyjny bł. Kingi, „Currenda” no. 149 (1999), Special issue, p. 56.

Chodkowski A., Bruckner Anton, in: Encyklopedia Muzyczna PWM, vol. 1 „ab”, ed. E. Dziębowska, Kraków 1979, p. 434.

De cantu sacro. Biuletyn Stowarzyszenia Polskich Muzyków Kościelnych, no. 8, ed. G. Poźniak, Opole - Lublin 2013, p. 72.

Garnczarski S., Pasionek Kazimierz, in: Polish Music. Polish Composers 1918-2010, edited by M. Podhajski, Gdańsk-Lublin, 2013, pp. 957-959.

Garnczarski S., Polska pieśń adwentowa w drukach od XVII do XX wieku, part. I, Tarnów 2014, pp. 191-192.

Jan Paweł II, „Mężczyzną i niewiastą stworzył ich...”, vol. III, Lublin 2001, http://www. kbroszko.dominikanie.pl/min_t3_2bc.htm (26.04.2019).

Jan Paweł II, General audience, August 13,2003 r. in: https://opoka.org.pl/biblioteka/ W/WP/jan_pawel_ii/audiencje/ag_13082003.html (26.04.2019).

Jan Paweł II, Homilia podczas mszy kanonizacyjnej bł. Kingi w Starym Saczu (16 VI 1999), „Currenda” No. 149 (1999), Special issue, p. 25.

Jarkiewicz K., Skromny, prosty i nie taki - Władysław Wojtoń SJ (1869-1948) w duszpasterstwie i edukacji, in: Studia i materiały do dziejów jezuitów polskich, eds. A.P. Bies, L. Grzebień, vol. 20 Społeczeństwo, kultura, wychowanie w poglądach polskich jezuitów okresu II Rzeczypospolitej, ed. S. Cieślak i B. Topij-Stępińska, Kraków 2012, pp. 89-117.

Komentarze biblijne do czytań mszalnych, Year A, ed. J. Homerski et al., Lublin 1981, p. 223.

Konieczna A., Gounod Charles, in: Encyklopedia Muzyczna PWM, vol. 3 „efg”, ed. E. Dziębowska, Kraków 1987, p. 410.

Ks. Teofill Jarynkiewicz, Ilustrowany Kuryer codzienny, no. 169, September 23,1918; Kraków, p. 4.

Skwarnicki Marek, https://www.znak.com.pl/autor/Marek-Skwarnicki(1.05.2019).

Msza święta i kanonizacyjna Błogosławionej Kingi. Stary Sącz 16 czerwca 1999, eds. B. Margański, A. Zając, S. Garnczarski, et al., Tarnów 1999, p. 13.

Nowak J., Kronika uroczystości kanonizacyjnych w Starym Sączu, „Currenda” No. 149 (1999), Special issue, p. 78.

Sojka S., Przygotowanie diecezji tarnowskiej na przyjazd Ojca Świętego Jana Pawła II do Starego Sącza, „Currenda” No. 149 (1999), Special issue, pp. 65-66.

Stefański J., Tu es Petrus, https://www.academia.edu/33984756/Ks._Jerzy_Stefa\%C5\%84ski_ -_Tu_es_Petrus, pp. 27-28.

Szkoła muzyczna I Stopnia w Tuchowie, http://www.sm.tuchow.pl/o-szkole/o-nas/ (1.05.2019).

Visitatio pastoralis Summi Pontificis Joannis Pauli PP. II in Polonia. Diebus 5-17 Junii A. Domini 1999, pp. 369-393. 